\title{
Cockles, mussels, fishing nets and finery: the relationship between cult, textiles and the sea depicted on a Minoan-style gold ring from Pylos.
}

\section{Caroline Tully}

The Griffin Warrior Ring No. 2 is a gold Minoan-style engraved signet ring from Pylos dating to the Late Helladic IIA (1580-1490 BCE). The ring's bezel depicts a seascape with a columnar tree shrine flanked by palm trees situated on a rocky outcrop. Five elaborately-dressed female figures stand on either side of the shrine. The tree shrine features a net pattern in the space between its stone or brick piers. It is proposed that this represents a fishing net and that the structure is a sea altar dedicated to an unnamed Minoan tree deity. The ring's hoop is decorated with cockle shells, further emphasizing its marine theme. It will be argued that the iconography alludes to marine food resources, practical and luxury textile fibres, sea trade, transculturality, and cult, and is testament to the importance of the sea in the Aegean Bronze Age.

Keywords: Minoan glyptic, Minoan religion, seascape, fishing, textiles

A recently discovered gold ring from Pylos depicts five elaborately-dressed female figures facing a shrine surmounted by a tree and flanked by palm trees, located on a rocky promontory above the sea. This article argues that the image represents a sea shrine which functions as a site where 
the different activities associated with the sea and textile production come together. In order to extrapolate the many activities and meanings that may be derived from the image, which has been miniaturized and concentrated in order to fit within the spatial parameters of the ring, the article first explains the reasons for interpreting the structure on the ring as a sea shrine focussed on a tree deity that also has power over the sea. It then demonstrates how the images on the ring, as well as the ring itself, are expressive of the micro-movements - or habitus - of fishing, collecting seafood, utilitarian textile production, and the relationship of these activities to cult. Examination of elaborate Minoan garments such as those worn by the female figures in the image highlights a thematic and a practical association with local harvesting of fish and molluscs, activities which are then shown to be inextricably linked to the larger international activities associated with Minoan international textile export and the spread of cloth and dye technology. The article concludes that the shrine exemplifies the social relations of mobility through its function as an interface between the sea and land, and its involvement in the flow between local and international groups of people (Leary 2014).

The Griffin Warrior Ring No. 2 is one of four gold signet rings recently discovered in a large stone-built tomb of Late Helladic IIA date (1580-1490 BCE) near Tholos Tomb IV, at the Palace of Nestor at Pylos on the Greek mainland (Davis and Stocker 2016: 638, fig. 8) (Fig. 1). The iconography of the ring is Minoan in style and it may have been of Minoan manufacture (Davis and Stocker 2016: 647). The image on the ring depicts (from left to right on the impression) two female figures wearing skirts with aprons, tight Minoan chitons, and tall hats, with their arms bent at $45^{\circ}$ angles and their hands raised to their faces - possibly to their mouths - in a cult salute, suggesting that they are priestesses (Fig. 2). They face a columnar tree shrine, the sides of which are constructed of stone or brick piers and the top or lintel of which features a row of 
circles, possibly alluding to beam ends. The altar is situated upon rocks, palm trees feature on each side of it, while on top of the structure is an unidentifiable tree, although it has been suggested to be ivy leaves on thick stem bases or a plane tree (Davis and Stocker 2016: 640, n.35; Moody 2017). To the right of the tree shrine are three female figures, the two smaller ones flanking the larger one. They have their hands on their hips, a gesture that has been interpreted as dancing, and may be deities or priestesses representing deities (Ulanowska 1993: 113-114; Tully 2016: 22). The three figures wear elaborate Minoan layered skirts, tight chitons, and have large, wide collars around their necks that appear to be made of pleated material and which evoke the form of Elizabethan ruffs. Attached to these collars are upward-curving objects that look like wings. That they are attached to the collars rather than the bodies of the figures suggests that they are some sort of garment decoration rather than intended to be actual wings. This is also the case in other examples of glyptic that depict similar compositions consisting of a large female figure flanked by two smaller ones: the stone seal CMS I No.159 from Mycenae also depicts the "wings" attached close to the figure's neck, perhaps to a necklace; and hints of this winged garment also appear on the clay sealing CMS II.6 No.1 from Haghia Triadha (Fig. 3).

In the Griffin Warrior Ring No. 2 both groups of figures stand on small dots, probably indicating either pebbles, similar to those depicted in the gold ring CMS I No.126 from Mycenae, or sand, and underneath this, as well as under the central rocky ground, is the familiar Minoan pattern indicating the sea (Fig. 4). The scene on the ring appears to be taking place on a beach, perhaps an inlet, or possibly a headland or promontory. Rocks also appear at the top of the image and this may further emphasise the rocky landscape or indicate that the scene occurs on an island (Davis and Stocker 2016: 640). While both groups of figures have parallels within other examples of 
Minoan glyptic, ${ }^{1}$ the large female figure flanked by two smaller figures on the right of the scene are also associated with another tree shrine image (Fig. 3). ${ }^{2}$

\section{<INSERT FIGURE 1 AROUND HERE>}

\section{$<$ INSERT FIGURE 2 AROUND HERE>}

Minoan tree cult is known primarily from glyptic evidence and falls into four main categories: trees in rocky ground; trees and walls; trees and cult structures; and trees and boats (Tully 2018a). Within the category of cult structure we find columnar structures, both stepped and straight-sided ashlar altars, tripartite shrines, constructed openwork platforms, incurved altars, and horned altars. The tree shrine on the Griffin Warrior Ring No. 2 falls into the class of columnar structures. There are two types of columnar structure: the more prevalent form is constructed from ambiguous, possibly wooden, material and the other type is apparently made from stone blocks or piers (Figs. 3 and 4). Columnar shrines are characterised by a simple post and lintel format consisting of columns, posts, or piers supporting a horizontal element such as a cornice or entablature. There is an opening between the columns or piers which is usually empty but which may contain additional vertical elements, sometimes interpreted as tree trunks or baetyls.

<INSERT FIGURE 3 AROUND HERE>

<INSERT FIGURE 4 AROUND HERE> 
Unusually, in the Griffin Warrior Ring No. 2, a net pattern features between the open spaces of the piers of the columnar shrine. This is unprecedented in Minoan-style cult scenes, although it may also be represented by the markings in the centre of the shrines depicted in the Archanes Ring and the Ring of Minos (Figs. 5 and 6). ${ }^{3}$ That the scene on the Griffin Warrior Ring No. 2 is set close to the sea, probably on a beach, may suggest that the net pattern indicates a fishing net draped over the shrine. While the markings in the centre of the shrines in the Archanes Ring and the Ring of Minos consist of simple crossed lines making a barely discernible diamond pattern which is more clearly evident in obvious depictions of nets in Aegean glyptic (fishing nets CMS IS No.58, II.6 No.133 and IV No.187, a bird net CMS II.6 No.123, and bull nets CMS IS No.53, II.6 No.48 and 49), the net pattern depicted on the Griffin Warrior Ring No. 2 differs from these because it includes dots at the intersections of the crossed lines, perhaps indicating knots. While all types of ancient hand-made nets are constructed of twisted (sprang) or knotted threads (Giner 2010: 62), the cockle shells decorating the ring's hoop contribute to a marine-themed interpretation (Fig. 7a and b). If the net pattern indicates a draped fishing net over the shrine, this may allude to a specific connection with the sea and maritime activities.

$<$ INSERT FIGURE 5 AROUND HERE>

$<$ INSERT FIGURE 6 AROUND HERE>

$<$ INSERT FIGURE 7a AROUND HERE> 


\section{$<$ INSERT FIGURE 7b AROUND HERE >}

I have argued elsewhere that Minoan tree shrines refer to an unnamed Minoan tree goddess who accumulated seafaring associations due to Minoan interaction with the eastern Mediterranean as a result of maritime mobility during the Middle Bronze Age and Late Bronze Age (Tully 2018a: 101-122; 2018b). This goddess was associated with fertility, nurturance, protection, regeneration, order, stability, and rulership, and also had power over boats, sailing and the sea (Rich 2010). Ancient seafarers engaged in beliefs and cultic practices centred on deities who oversaw maritime, celestial or meteorological phenomena. Sea shrines, such as that depicted in the Griffin Warrior Ring No. 2, were set up upon prominent landmarks which were also often locations of fresh water (Brody 1988: 13-19, 39-61). The shrines depicted on this ring, as well as on the Ring of Minos, may represent sacred mountains or promontories that functioned as landmarks for sailors. In addition to functioning as a focal point for sailors coming in from the sea, the netted shrine on the Griffin Warrior Ring No. 2 may also have been used by land-based people going to, or focusing on, the sea for various reasons. So what can we extrapolate from this image of elaborately dressed female cult practitioners at a tree shrine on the seashore?

At first glance, the net in conjunction with the seascape suggests fishing. Various types of fishing nets were used in the Bronze Age Aegean, cast from boats and the shore. Iconographic representations of beach seines are evident and a trammel net may also be depicted, but the best evidence for fishing nets are lead net weights (Powell 1992; 1996; Rose 1994). The fishing theme is enhanced by the cockle shells on the hoop of the ring. Fishing and collection of marine invertebrates required an understanding of the seasons of fish migration as well as the most favorable periods for their fishing and collection (Karali 1996). The cockle is the most 
frequently-represented bivalve in Minoan art; however, cockles appear on only two pieces of jewellery: this ring and a non-sphragistic gold ring from the Áyios Charalambos Cave (Muhly 2014; Betancourt 2011; Pini 2010) (Fig. 8a, b and c).

$<$ INSERT FIGURE 8a AROUND HERE >

$<$ INSERT FIGURE 8b AROUND HERE >

$<$ INSERT FIGURE 8c AROUND HERE >

In addition to referring to the sea, cockle shells and nets also have cultic associations. Real, often painted, as well as faience skeumorph cockle shells feature in the Temple Repositories assemblage from Knossos (Evans 1921: 517, figs. 377, 378, 379; Panagiotaki 1999: 128-131). A net pattern is depicted on Middle Minoan "talismanic" seals, sometimes in association with boats and fish. Nets are draped across the backs of bull figurines from Pseira in eastern Crete, perhaps evoking the act of catching the bull in the wild, as seen on the "violent" gold cup from Vapheio (Guest-Papamanoli 1996; Betancourt 2007, 85, 188). Minoan glyptic scenes of animal sacrifice primarily occur in the vicinity of palm trees, an association that may apply to the palm trees on either side of the netted shrine. Palm trees are also associated with the cultic aspects of seafaring, as is evident on the seal CMS VS IA No.55 from Makrygialos depicting a female figure performing a cultic gesture towards a palm tree in a boat; they represent goddesses and evoke rulership in Near Eastern art, as can be seen in the Investiture Fresco from Mari; sculpted or 
painted palm trees flanked the entrances to Near Eastern sanctuaries; and they are symbolic of fertility, prosperity and general good fortune in Egyptian art (Buhl 1947; Jacobsen 1976; Marinatos 1984, 1986; Black and Green 1992; Kantzios 1999; Davaras 2004; Giovino 2007: 182; Kupitz et. al. 2009; Matsushima 2014).

The net is also a textile which would have been made of hemp or hair fibres. In order to construct nets - whether for use on land or in the sea - knowledge of textile techniques such as spinning, knitting and knotting would have been necessary. Nets require a consistent size of mesh which can only be achieved with a series of regular loops or knots which can also be kept in place by spacers made of wood or other material, as may be seen on the Griffin Warrior Ring No. 2 as well as on a gold seal found in a tomb at Pylos (Fig. 9). Nets required floats which could be made from materials such as wood, bark, pumice, gourds or pots, and also weights which were made from metal or stone - even loom weights could have been used if they were sufficiently fired (Powell 1992: 105-106).

\section{<INSERT FIGURE 9 AROUND HERE >}

The fishing net is an example of a utilitarian textile, in contrast to which the female figures depicted on the ring wear elaborate textiles. It is unlikely that these women were going fishing in such garments; rather, their clothing evokes the multiple connections between Minoan textiles and the sea: wall paintings depict the net motif on elaborately-patterned polychrome Minoan textiles; one of the dyes used to colour such textiles was sea purple derived from the marine gastropod, Hexaplex trunculus; elite textiles may have been constructed from or featured sea 
silk, golden fibres produced by the Mediterranean bivalve, Pinna nobilis; Minoan textiles were exported through sea trade; and Minoan textile technology was also disseminated over the sea (Papageorgiou 2014; Murray 2016; Chapin 2008, 2016; Ruscillo 2002; Pareja, Betancourt, Apostolakou, Brogan and Koh 2016; Burke 1999, 2012; Burke and Chapin 2016; Reese 1987; Soriga and Carannante 2017; Barber 1990; Cutler 2012; Kremer 2017).

While evoking the sea, the net pattern also references fabric patterns used in both Minoan clothing and wall hangings. The net pattern features on the apron of the Snake Priestess from the Temple Repositories at Knossos, on the garment of the Lady in Red from Knossos, and the skirt of the moulded fresco figure of Lady B at Pseira. Several female garments from the frescoes depicted on the walls of Xeste 3 at Akrotiri, Thera, feature net patterns. It appears on the cloaks of Minoan Geniuses, as part of the tasselled decoration on male kilts in the Procession Fresco from Knossos, and in fresco images of female garments from Pylos. ${ }^{4}$ As a wall hanging or decoration, the net pattern features in frescoes from Poros-Katsambas on Crete and Xeste 3 and the House of the Ladies at Akrotiri (Shaw 1998; Betancourt 2007; Papageorgiou 2014; Murray 2016: $46-49,60-78,87,93 \mathrm{n} .18$ ). When used in a decorative capacity, the net pattern probably functioned as a multivocal symbol that evoked associations of the sea and hunting, as well as cult (Krzyszkowska 2014; Papageorgiou 2018).

The net pattern features on the short-sleeved bodices dyed with murex purple of the garments worn by the Basket-Bearer and the Lily-Bearer from the Corridor of the Procession at Xeste 3 on Thera (Chapin 2008: 55-56). While we cannot see the colours used in garments depicted in Minoan glyptic, frescoes show that female costume was multicoloured, and residue analysis of pottery from Alatzomouri-Pefka has found evidence of red, yellow and purple dyes (Pareja, Betancourt, Apostolakou, Brogan and Koh 2016: 23-24). Murex or "sea-purple" dye derives 
from the hypobranchial gland of Mediterranean shallow water molluscs such as Hexaplex trunculus. The dye ranges from purplish-red, to shades of violet up to blue and, due to the small amount of colourant able to be extracted from each mollusc, was highly valued. The earliest evidence for the practice of extracting and dying with sea-purple indicates that it originated on Crete (Burke 1999: 79). ${ }^{5}$ Shells of Hexaplex are present at Neolithic Knossos and purple textiles may have been a major commodity traded from Crete, possibly in exchange for precious metals or other resources, as early as $2500 \mathrm{BCE} .^{6}$

The earliest evidence for dye-extraction on Crete consists of large quantities of murex shells found on the island of Kouphonisi, at Petras, Palaikastro, and Kommos which date to the Early to Middle Minoan period (Reese 1987; 1995; 2016; 2019; Burke 1999, 2010; Ruscillo 2005; Chapin 2008; Kremer 2017). ${ }^{7}$ Evidence of purple dye from Pyrgos-Mavroraki on Cyprus dates to the first half of the $19^{\text {th }}$ century BCE; textual evidence suggests that imported purple-dyed cloth was known at Mari by the $18^{\text {th }}$ century BCE; purple dyeing technology appears on the Greek mainland by the late Middle Bronze Age, at Troy during the Middle to Late Bronze Age transition, at Minet el-Beida, Sarepta and Akko by the Late Bronze II-III, and at other sites on the Levantine coast as late as the $15^{\text {th }}-14^{\text {th }}$ centuries BCE (Burke 1999; Reese 2010, 2018, 542; Cutler 2012; Carannante 2014; Burke and Chapin 2016; Kremer 2017; Soriga 2017).

As well as dyestuff from the sea it is likely that the Minoans were aware of shellfish that produced fibre. While around twenty different species of related molluscs produce fibres that can be utilised in textile construction, the most frequently harvested type was from the fan shell, Pinna nobilis, because it produces the finest fibres (Montegut 1999). Known as byssus or seasilk, the fibre comes from the "beard" of this bivalve which consists of filaments that the mollusc uses to anchor itself to the seabed (McKinley 1998). After harvesting and processing, the 
resulting sea-silk consists of golden coloured fibres that can reach up to 1 meter in length. Like sea-purple, only small amounts of sea-silk can be obtained from each shellfish. Pinna shell remains have been found in multiple locations in the Central and Eastern Mediterranean at Neolithic and Bronze Age sites. On Crete Pinna shells have been found in a Late Minoan context at Khania and while this does not definitively equate to the use of sea-silk fibres, it is suggestive (Burke 2012: 4; Reese 2016).

The three female figures with their hands on their hips in the Griffin Warrior Ring No. 2 wear flounced skirts consisting of layers that appear to be made of separate strands gathered into fringes, rather than a woven fabric. Minoan garments with this sort of shaggy appearance are well-known and while most were probably made of wool some, such as the flounced skirt, may have been made of, or incorporated, sea-silk fibres. The West House at Akrotiri contained significant numbers of Pinna shells and Burke has proposed that the shaggy robe worn by the "Young Priestess" from the West House was made of sea-silk fibres (Karali-Yannacopoulou 1990; Burke 2012). Pinna shells and fragments have also been recovered at numerous contexts at Mycenae, including in Room 18 ("the Temple") and in the vicinity of the Cult Centre (Rooms 23-35, Late Helladic IIIB2). Burke further suggests that the female figure in the fresco in the Cult Centre at Mycenae, usually interpreted as holding bunches of grain, instead holds Pinna shells. A Late Helladic I ring from Aidonia may feature Pinna shells, evoking the exotic sea fibre as a source of elite textile decoration (Kaza-Papageorgiou 2006; Pini 2010; Burke 2012; Jones 2015; Reese in press) (Fig. 10).

$<$ INSERT FIGURE 10 AROUND HERE> 
Not only were Minoan textiles embellished by products harvested from the sea, they were also exported over the sea (Burke 2016). Textiles were highly valued commodities in the eastern Mediterranean during the Bronze Age, and evidence for textile production at Early Minoan II Myrtos (c. 2600-2200 BCE) includes an array of facilities and tools (for wool processing and dye production, spindle whorls and loom weights) that enabled the production of multicolour patterned fabric, as well as the presence of the earliest known spinning bowls, a tool that may have originated on Crete and spread to the Near East and Egypt from around the mid-third millennium BCE (Barber 1991: 74-76; Burke and Chapin 2016: 28-29, 35).

The Minoan warp-weighted loom was suited to the production of large, wide textiles with elaborate patterns, in contrast to the horizontal ground looms of Egypt and Mesopotamia. In the early second millennium, textiles are among the luxury gifts carried by the Keftiu (commonly identified as Cretans) depicted in $18^{\text {th }}$ Dynasty Theban tomb paintings; Aegean textile patterns appear in $18^{\text {th }}$ Dynasty Egyptian paintings of boats where they decorate the cabins; as spirals, scrolls, interlinked quatrefoils, and bulls' heads with rosettes between the horns decorating the ceilings in a number of Egyptian tombs dating to between the $12^{\text {th }}$ and the $21^{\text {st }}$ Dynasties; and in the $14^{\text {th }}$ century BCE robing room in the palace of Amenhotep III at Malkata near Thebes, the ceiling of which is decorated with bulls' heads with rosettes amid running spirals around more rosettes (Cutler 2012: 151; Phillips 2010: 882-4; Barber 1994; 2016: 205-237). ${ }^{8}$ There was significant demand for such exotic textiles in the contemporary Eastern Mediterranean and decorated and purple dyed textiles from Crete were a unique commodity in the international market (Burke 1999: 25-27; Cutler 2012). ${ }^{9}$

As well as Minoan textiles, the technology used in their production was also exported overseas. A bowl featuring an interior "handle" or loop with a worn area under the loop caused by the 
movement of thread against it, used for wetting flax fibre in order to facilitate easier spinning, and a fragment of another such bowl, found at Early Minoan Myrtos suggests a Cretan origin for a flax-spinning method (Warren 1972: 153, 207, 209; Barber 1991: 74-75). This type of bowl may have been adopted by the Egyptians: the only Egyptian image of spinning that is contemporary with the Early Minoan II period, on a relief dating to the $6^{\text {th }}$ Dynasty, does not include the spinning bowl, its earliest Egyptian representation being a model from an 11th Dynasty tomb (Barber 1991: 75-77). The wide distribution of the ubiquitous Minoan discoid loom weight in the Aegean from the Middle Bronze Age suggests the transmission of a specific Cretan weaving style through the adoption of the warp-weighted loom (Cutler 2012: 146-147; Kremer 2017: 100-103). The depiction of figures wearing Minoan style patterned garments in the wall paintings of Akrotiri, Ayia Irini, Melos, and Late Helladic III mainland frescoes suggest that both the warp-weighted loom and Minoan dyeing techniques were adopted in order to produce Cretan-style fabrics (Cutler 2012: 151; Kremer 2017: 101). It is most likely that women were responsible for textile production on Crete during the Minoan period, as was the case in the Eastern Mediterranean, Near East, and during the Mycenaean period on Crete and the Greek mainland, and that some of those women with expertise in Minoan-style weaving travelled outside Crete in order to teach the techniques to local communities in the southern Aegean. Minoan-style discoid loom weights present at some sites in the southern Aegean and made of fabrics that are consistent with Cretan clays suggest that the female craftspeople brought them to those locations, perhaps to be used as templates for the manufacture of the many examples made from local clays (Cutler 2012: 149-150). There is also a general correlation of the discoid loomweight with the spread of purple dyeing (Kremer 2017: 101). 
In conclusion, the presence of elite women wearing elaborate textile garments at a sea shrine, as depicted on the Griffin Warrior Ring No. 2, may refer to cult focussed upon all the aspects of the Minoans' relationship with the sea. From the micro-gestures associated with catching and collection of sea foods and harvesting of fabric dyes and materials, to the expansive macromovements involved in the overseas textile trade. It is reasonable to propose therefore that these female figures were enacting cultic tribute at this shrine in acknowledgment of its function as a node that linked sites, exemplified the convergence between sea and land, and the mobilisation of people, ideas, objects and information.

CAROLINE TULLY is an Honorary Fellow in the School of Historical and Philosophical Studies at the University of Melbourne, Australia. She has a Bachelor of Arts in Fine Art from Monash University, Graduate and Postgraduate Diplomas in Classics and Archaeology and a PhD in Aegean Archaeology from the University of Melbourne. Caroline's research interests include religion and ritual in the Bronze Age Aegean and East Mediterranean, reception of the ancient world, and contemporary Pagan religions. Her publications include Celtic Egyptians: Isis priests and the lineage of Scota (2020), The artifice of Daidalos: Modern Minoica as religious focus in contemporary Paganism (2019), The Cultic Life of Trees in the Prehistoric Aegean, Levant, Egypt and Cyprus (2018), Thalassocratic Charms: Trees, Boats, Women and the Sea in Minoan Glyptic Art (2018), Egyptosophy in the British Museum: Florence Farr, the Egyptian Adept and the Ka (2018), Virtual Reality: Tree Cult and Epiphanic Ritual in Aegean Glyptic Iconography (2016), and Walk Like an Egyptian: Egypt as Authority in Aleister Crowley's Reception of The Book of the Law (2010). From 1996 to 2010 Caroline was a professional 
tapestry weaver at the Australian Tapestry Workshop and she maintains an interest in textiles, particularly the garments of Minoan Crete. caroline.tully@unimelb.edu.au

\section{Acknowledgments}

The author would like to thank Jack Davis, Sharon Stocker, Carol Hershenson, Efi SapounaSakelleraki, Ingo Pini, Katie Demakopoulou and the Corpus der Minoischen und Mykenischen Siegel for permission to reproduce images, and David S. Reese for his generous assistance in regard to the archaeological evidence for shells in the Aegean and wider Mediterranean.

\footnotetext{
NOTES

${ }^{1}$ CMS I No.159; II 3 No.218; II 3 No.236; II 6 No.13; XII No.168.

${ }^{2}$ CMS II 6 No.1.

${ }^{3}$ HM 989 and HM 1700. Although these are usually interpreted as spirals of the type seen on the shrine facade depicted on the Peak Sanctuary Rhyton from Zakros.

${ }^{4}$ The tricurved arch pattern which is used in glyptic to depict the sea and is similar to the net pattern was also utilised as a textile motif, as seen on one of the skirts of the Mycenae Ivory Triad and on a fragment of a female garment from Tiryns.

${ }_{5}^{5}$ The Bronze Age site of Coppa Nevigata (Apulia, Italy) has been proposed, although not confirmed, to precede Crete (Reese 2005, 110-111). Alberti (2006) has suggested a multi-regional genesis of purple dye production in coastal regions where murex and textiles coincided.

${ }^{6}$ While there are 17 Hexaplex (with eight collected dead) at Neolithic Knossos there is no evidence for purple dyeing (Reese, unpublished manuscript).

${ }^{7}$ See also Carannante 2014, 274. For comprehensive presentation of the evidence for purple dye production on Crete see Reese 2016 and 2019.

${ }^{8}$ As Atchity and Barber $(1987,18)$ note, women at home were busy manufacturing a major item for the men's export trade: textiles. The Aegean traders in Egyptian wall paintings are consistently male.

${ }^{9}$ It is likely that Minoan merchants were trading textiles and manufactured metal goods in exchange for raw materials. In some records we see that the value of certain textiles was assessed in terms of metals, acting as nearly a kind of currency. Textiles provided a valuable source of wealth for the Minoan palaces which was further utilised to maintain and finance social, religious, and economic institutions (Chapin 2016, 239).
} 


\section{University Library}

\section{- M M N E R VA A gateway to Melbourne's research publications}

Minerva Access is the Institutional Repository of The University of Melbourne

Author/s:

Tully, C

Title:

Cockles, Mussels, Fishing Nets, and Finery: The Relationship between Cult, Textiles, and the Sea Depicted on a Minoan-Style Gold Ring from Pylos

Date:

2020-10-14

\section{Citation:}

Tully, C. (2020). Cockles, Mussels, Fishing Nets, and Finery: The Relationship between Cult, Textiles, and the Sea Depicted on a Minoan-Style Gold Ring from Pylos. Journal of Eastern Mediterranean Archaeology and Heritage Studies, 8 (3-4), pp.365-378. https:// doi.org/10.5325/jeasmedarcherstu.8.3-4.0365.

Persistent Link:

http://hdl.handle.net/11343/252770

License:

Unknown 